\title{
CONTRIBUTIONS TO THE STUDY OF THE CHOROLOGY AND CONSERVATION STATUS OF LYCOPODS IN MUREŞ COUNTY
}

\author{
Mihaela SĂMĂRGHIŢAN ${ }^{1 *}$, Silvia OROIAN ${ }^{2}$ \\ ${ }^{1}$ Mureş County Museum, Natural Science Department, 24 Horea Street, RO-540036, Târgu Mureş, \\ ${ }^{2}$ University of Medicine, Pharmacy, Science and Technology „George Emil Palade” of Târgu-Mureș, \\ Faculty of Pharmacy, 38 Gheorghe Marinescu Street, RO-540139 Târgu-Mureş
}

*Correspondence:
Mihaela SĂMĂRGHIŢAN
msamarghitan@yahoo.com

Received: 13 December 2019; Accepted: 20 December 2019; Published: 30 December 2019

\begin{abstract}
This paper presents the obtained results on the chorology and conservation status of the lycopod species identified in Mureș County. It also represents a basis for further studies on monitoring, and establishes conservation measures for these species that are of community interest, included in the IUCN category LC (least concern). During the study, five lycopod species out of the seven listed in Romania were identified. The species are wide spread, occurring in groups that extend over relatively large areas. The conservation status is predominantly good and very good.
\end{abstract}

Keywords: lycopods, distribution, specific diversity, conservation.

\section{Introduction}

The Lycopodiaceae family is an ancient, cosmopolitan family of over 400 species (Øllgaard and Windisch, 2014).

Lycopodiaceae are composed of three genera: Huperzia, Lycopodiella and Lycopodium, which differ in characters of branching patterns, the presence or absence of modified leaves, spore morphology, gametophyte shape, and chromosome number. Many lycopods have underground gametophytes that make an obligatory association with fungi (Merckx et al., 2012).

In Europe, 14 species of Lycopodiaceae are encountered, of which 3 are endemic (García Criado et al., 2017). In Romania, the family Lycopodiaceae comprises 7 species (Sârbu et al., 2013). They are widespread from the mountain area to the alpine area, in the alpine bioregion. They prefer the shady forests, the peat bogs, and the edge of the shady hills, the rocks, and the grassy places at the top of the mountains (Mihăilescu et al., 2015).

Despite the fact that they are widespread, in Europe all species of the genus Lycopodium have shown a general decline in abundance and have therefore been included in Annex $\mathrm{V}$ of the Habitats Directive 92/43/CEE, and 5A Annex of Romanian Government Ordinance 57/2007. Lycopodium clavatum in particular, is also included in Annex D of the Council Regulation 
(EC) No 338/97 on the protection of species of wild fauna and flora by regulation their trade. Therefore, it is necessary to establish conservation measures. Knowing the distribution and conservation status of the lycopod species will be vital in establishing these measures.

The present study contributes to the knowledge of lycopod species distribution in the area of Mureș County and it gives us a base for future research about population dynamics and conservation trend.

\section{Materials and Methods}

Data from the literature as well as the field observations during 2012-2019 were taken into account for the study of the Lycopodiaceae family in Mureș County. Some of the locations specified in the literature have been confirmed. Also, numerous new locations with representative populations of the studied species were recorded using the Global Positioning System (GPS).

The method of transects was applied for the field study. Transects were established on the main river valleys that cross the territory: Mureş Gorge, Gurghiului Valley and Niraj Valley, as well as their tributaries. Each point where the studied species were encountered was noted and their abundance was estimated.

The studied territory, represented by the mountain area of Mureș County (Călimani and Gurghiului Mountains), extends on a vegetation belt, namely the mountain belt. The vegetation studies from these areas highlight the presence of the forests characteristic of this sector, namely beech forests belonging to the Carpino-Fagetea class and spruce forests of the Vaccinio-Piceetea class (Oroian, 1998, Sămărghiţan 2005), which are typical habitats for the development of lycopod species.

In order to establish the frequency at the national level, and the biological and ecological characteristics of the species, the works of
Ciocârlan (2009), Oprea (2005) and Sârbu et al. (2013) were taken into account. For each observation point, location data (GPS coordinates), altitude, and abundance data were recorded. In order to evaluate the abundance a 5-level scale was used. In this scale, we considered the range of cover of aboveground shoots $/ \mathrm{m}^{2}$. The 5 levels are: D-dominant $(80-$ $100 \%)$, A-abundant (60-80\%), F-frequent (40$60 \%)$, O-occasional (20-40\%), and R-rare (1$20 \%$ ). Considering the altitudinal gradient 9 elevation levels were used: 1 (501-600 m), 2 (601-700 m), 3 (701-800 m), 4 (801-900 m), 5 (901-1000 m), 6 (1001-1100 m), 7 (1101-1200 $\mathrm{m}), 8$ (1201-1300 m), and 9 (> $1300 \mathrm{~m})$.

\section{Results and discussions}

In Mureș County five out of the seven lycopod species that grow in Romania were identified. These are: Huperzia selago (L.) Schrank et Martins (Lycopodium selago L.), Lycopodium alpinum L., Lycopodium annotinum L., Lycopodium clavatum L., and Lycopodium complanatum L (Fig. 1-3).

These species occur in the mountain area of the county, mainly Călimani and Gurghiului Mountains. They are widespread in their characteristic habitats such as woods, and mountain grasslands. Regarding the distribution and frequency at the national level, all 5 studied species are sporadic and none are rare or occasional (Table 1.).

In the study area, 201 records of the five species of lycopods were noted. The most common populations are those with Lycopodium annotinum, and Lycopodium clavatum, which often occur together in the studied territory the two species being identified in several cases at the same locations.

The studied species were found in forests, forest edges, shrubs and meadows. They have clonal growth and are frequently distributed in small groups but spread over a large area. 

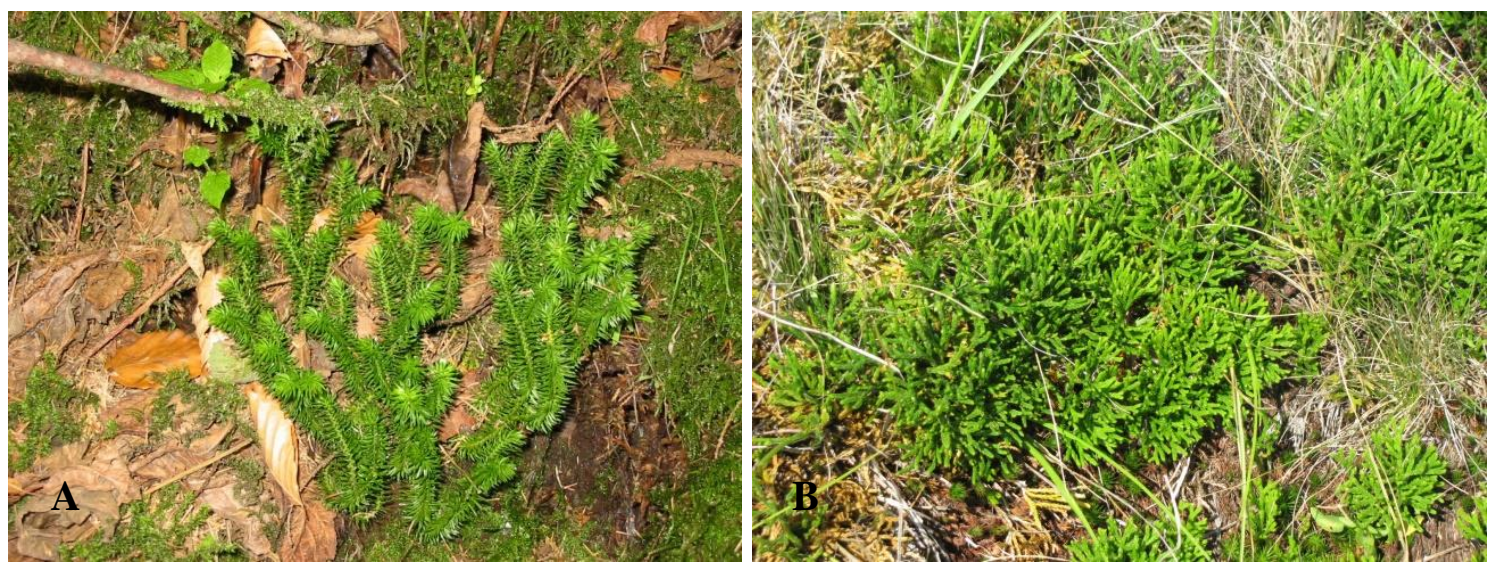

Fig. 1. Lycopods from Mureș County, Romania: A. Huperzia selago (Neagra Valley); B. Lycopodium alpinum (Iodului Valley) (Photos: Silvia Oroian)
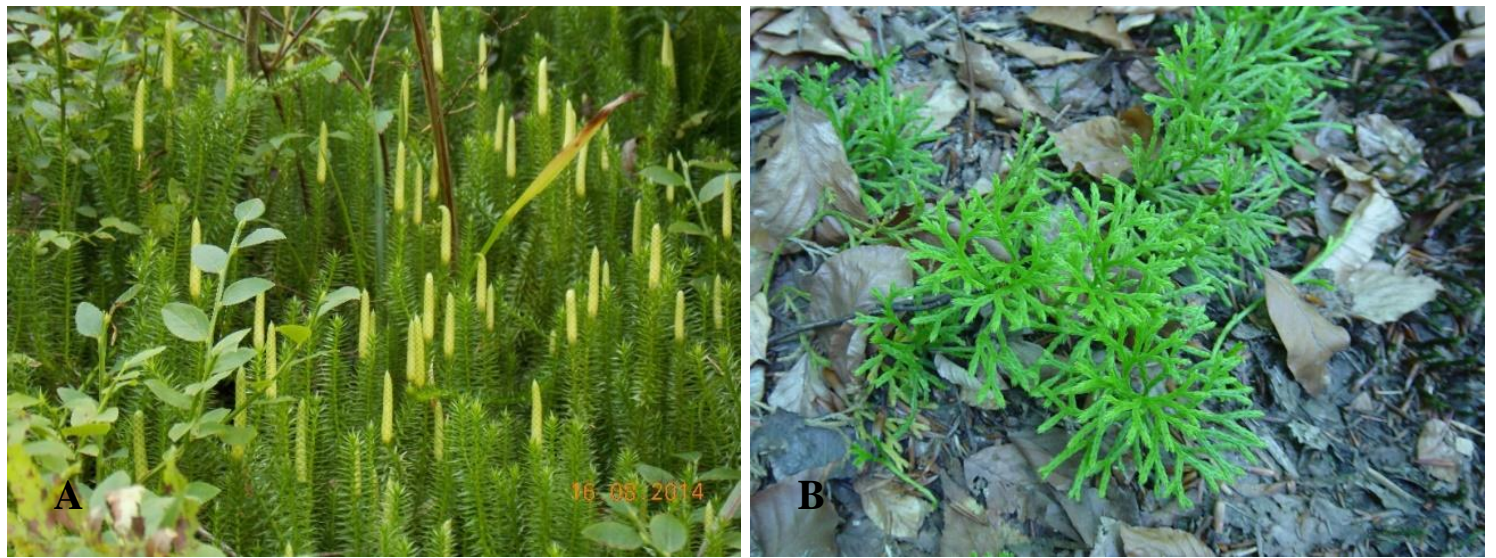

Fig. 2. Lycopods in Mureș County, Romania: A. Lycopodium annotinum (Secuieu Valley); B. Lycopodium complanatum (Răstolița) (Photos: Mihaela Sămărghițan and Silvia Oroian)
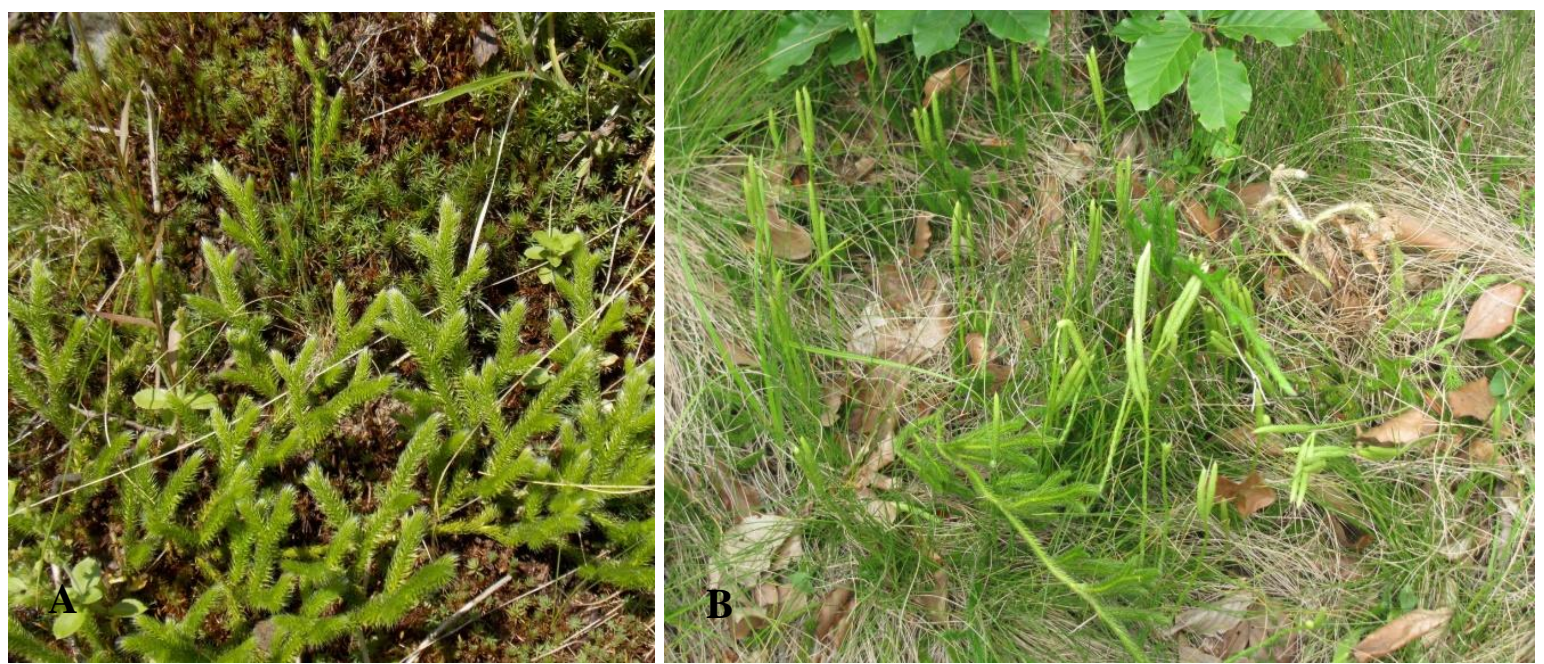

Fig. 3. Lycopodium clavatum in Mureș County, Romania: A. in Sovata Valley (Mureș County, Romania); B. in Stânceni (Photos: Mihaela Sămărghițan and Silvia Oroian)

Huperzia selago (L.) Schrank et Martins (Lycopodium selago L.) is widespread in the studied area, being recorded in 30 locations
(Fig. 4.). It is a characteristic species of the Vaccinio-Piceetea class Br.-Bl. in Br.-Bl. et al. 1939 (Coldea, 2015), being identified in 
acidophilic spruce forests belonging to this class as well as in Dacian beech forests of Symphyto-Fagion. This species participates in the composition of herbaceous synusia of the associations Hieracio transsilvanici-Piceetum
Pawłowski et Br.-B1. 1939 and Leucanthemo waldsteinii - Fagetum (Soó 1964) Täuber 1987 sometimes with significant dominance values, up to $20 \%$.

Table 1. Lycopods identified in Mureș County; their frequency and distribution on national level; biological and ecological characteristics.

\begin{tabular}{|l|l|l|l|l|}
\hline \multicolumn{1}{|c|}{ Species } & $\begin{array}{l}\text { Frequency } \\
\text { on the } \\
\text { national } \\
\text { level }\end{array}$ & \multicolumn{1}{|c|}{$\begin{array}{c}\text { Distribution on } \\
\text { national level }\end{array}$} & \multicolumn{1}{|c|}{$\begin{array}{c}\text { Biological } \\
\text { characteristics }\end{array}$} & Ecological features \\
\hline Huperzia selago & Sporadic & $\begin{array}{l}\text { In the spruce forests } \\
\text { belt, wet grassy } \\
\text { places, forests, } \\
\text { bushes, peatlands }\end{array}$ & $\begin{array}{l}\text { Perennial, Ch, } \\
2 \mathrm{n}=90,264,272, \mathrm{P}\end{array}$ & $\begin{array}{l}\text { Moderate } \\
\text { acidophilous } \\
\text { oligotrophic, meso- } \\
\text { hygrophilous, } \\
\text { scyophilous-helio- } \\
\text { scyophilous, } \\
\text { microthermal, } \\
\text { calciphilous }\end{array}$ \\
\hline $\begin{array}{l}\text { Lycopodium } \\
\text { alpinum }\end{array}$ & Sporadic & $\begin{array}{l}\text { In the spruce forests } \\
\text { belt, grasslands, } \\
\text { shrubs }\end{array}$ & $\begin{array}{l}\text { Perennial, Ch, } \\
2 \mathrm{n}=46-48-50, \mathrm{P}\end{array}$ & $\begin{array}{l}\text { Oligotrophic, } \\
\text { mesophilous }\end{array}$ \\
\hline $\begin{array}{l}\text { Lycopodium } \\
\text { annotinum }\end{array}$ & Sporadic & $\begin{array}{l}\text { In the beech and the } \\
\text { spruce belt; in wet } \\
\text { places, marshes, } \\
\text { hedges, forests, and } \\
\text { peatlands }\end{array}$ & $\begin{array}{l}\text { Perennial, Ch, } \\
2 \mathrm{n}=68, \mathrm{P}\end{array}$ & $\begin{array}{l}\text { acidophilous, } \\
\text { oligotrophic, } \\
\text { mesophilous-meso- } \\
\text { hygrophilous, helio- } \\
\text { scyophilous - } \\
\text { scyophilous, } \\
\text { calcifuge }\end{array}$ \\
\hline $\begin{array}{l}\text { Lycopodium } \\
\text { clavatum }\end{array}$ & Sporadic & $\begin{array}{l}\text { From the oak to the } \\
\text { spruce forests belt in } \\
\text { shrub land, grasslands, } \\
\text { forest fringes }\end{array}$ & $\begin{array}{l}\text { Perennial, Ch, } \\
2 \mathrm{n}=68, \mathrm{P}\end{array}$ & $\begin{array}{l}\text { Acidofilous, } \\
\text { oligotrophic, eury- } \\
\text { philous, helio- } \\
\text { scyophilous - } \\
\text { scyophilous, } \\
\text { calcifuge }\end{array}$ \\
\hline complanatum & Sporadic & $\begin{array}{l}\text { In the beech and the } \\
\text { spruce forests belt, in } \\
\text { forests and shrubs }\end{array}$ & $\begin{array}{l}\text { Perennial, Ch, } \\
2 \mathrm{n}=46, \mathrm{P}\end{array}$ & $\begin{array}{l}\text { Oligotrophic, } \\
\text { calcifuge }\end{array}$ \\
\hline
\end{tabular}

In the study area the highest abundance and frequency values were recorded for the species Lycopodium annotinum L. It was identified in 109 locations, sometimes dominant in the grass layer of acidophilic spruce forests (Bătrâna Valley AD2, Lăpuşna AD1, Şirodului Valley AD1). In the study area it appeared most commonly in the coenoses of plant associations Hieracio transsilvaniciPiceetum Pawłowski et Br.-Bl. 1939 and
Sphagno girgensohnii-Piceetum Kuoch 1954. It is also present in the composition of beech forests included in the association Leucanthemo waldsteinii-Fagetum (Soó 1964) Täuber 1987. Significant populations were also encountered near the mountain forests of the Vaccinio-Piceetea class; also entering in the composition of habitat 6440 . These coenoses dominated by Deschampsia caespitosa are distributed linearly along mountain valleys. 
The variety of habitats of community interest in which this species is encountered (Table 2.) as well as the high density of the above ground shoots observed on large surfaces (a large number of small areas) justifies the affirmation that the species is well represented and frequent in the studied territory.

Along with Lycopodium annotinum, sometimes sharing the same area, Lycopodium clavatum L. has also been identified. In the study area the populations of L. clavatum were distributed at altitudes between 563 and 1371 $m$ asl (Scaunul Domnului Peak). The identified populations are represented by vigorous individuals, well developed on surfaces ranging from a few square meters to dozen of square meters. This species grows very well in the forest cuts, and in the clearings. It was encountered along the studied paths both in forest habitats, spruce forests belonging to the Vaccinio-Piceetea class and in pastures habitats in fragmented micro-areas wide spread on large areas (Table 2.).

Lycopodium alpinum L. and Lycopodium complanatum L. were present in the studied territory, but have a limited spread. These species are included in the national red lists under the category R (Rare) (Oltean et al., 1994).

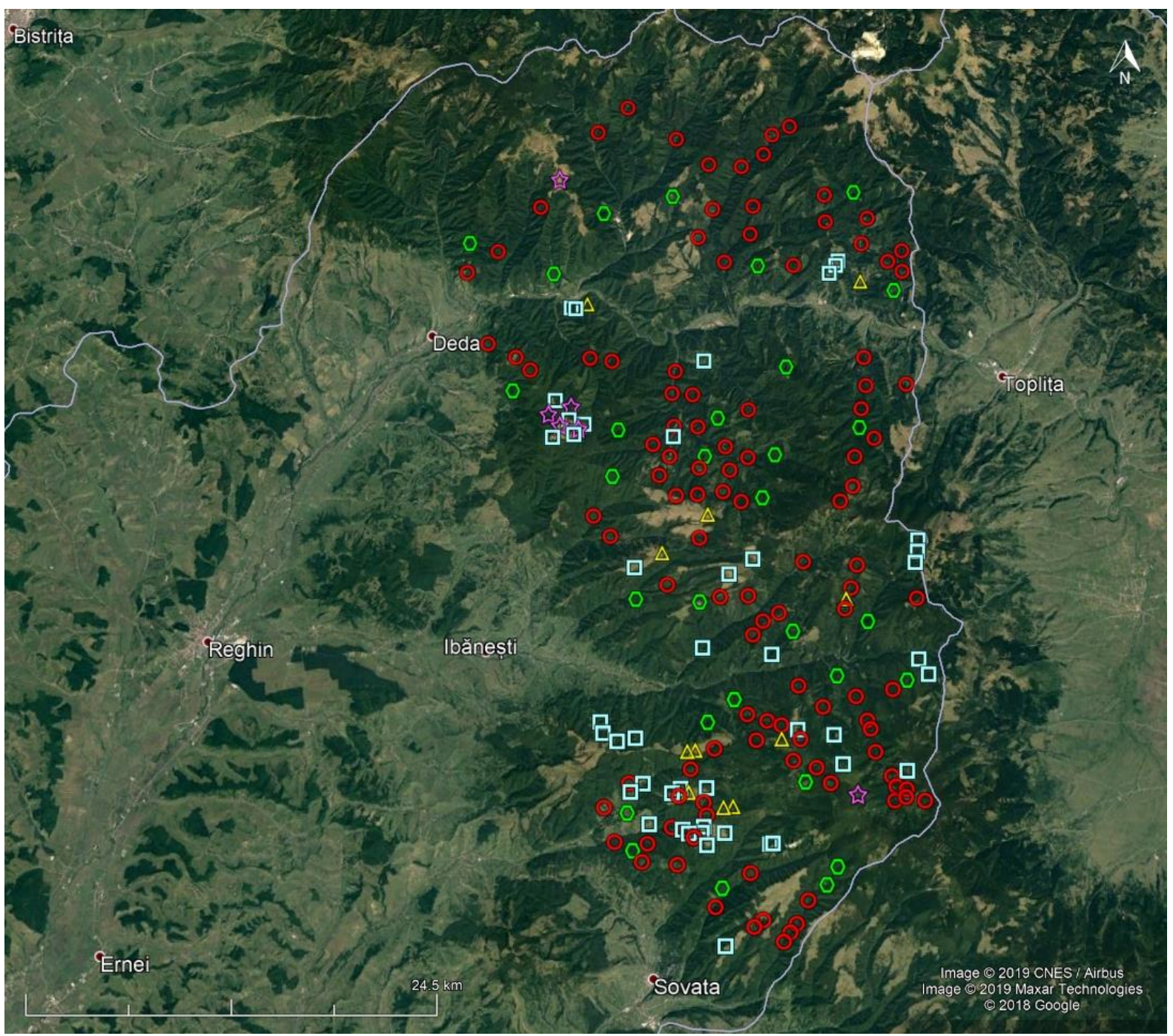

Fig. 4. The distribution map of the studied lycopod species (Mureș County, Romania): OHuperzia selago, OLycopodium annotinum, Lycopodium complanatum, $\square$ Lycopodium clavatum, and is Lycopodium alpinum 
Table 2. The Natura 2000 habitat types in which the studied lycopod species were identified (Mureș County, Romania)

\begin{tabular}{|l|l|}
\hline \multicolumn{1}{|c|}{ Natura 2000 Habitat } & \multicolumn{1}{c|}{ Species } \\
\hline $\begin{array}{l}\text { 9410 Acidophilous Picea forests from the mountain to } \\
\text { the alpine level (Vaccinio-Piceetea) }\end{array}$ & $\begin{array}{l}\text { Huperzia selago, Lycopodium annotinum, } \\
\text { Lycopodium clavatum, Lycopodium } \\
\text { complanatum }\end{array}$ \\
\hline $\mathbf{9 1 V 0}$ Dacian Beech forests (Symphyto-Fagion) & Huperzia selago, Lycopodium annotinum \\
\hline $\begin{array}{l}\text { 6230* Species-rich Nardus grasslands, on silicious } \\
\text { substrates in mountain areas }\end{array}$ & $\begin{array}{l}\text { Lycopodium alpinum, Lycopodium } \\
\text { clavatum }\end{array}$ \\
\hline $\begin{array}{l}\mathbf{6 4 4 0} \text { Alluvial meadows of river valleys of the Cnidion } \\
\text { dubii }\end{array}$ & $\begin{array}{l}\text { Lycopodium annotinum, Lycopodium } \\
\text { clavatum }\end{array}$ \\
\hline $\mathbf{6 5 2 0}$ Mountain hay meadows & $\begin{array}{l}\text { Lycopodium clavatum, Lycopodium } \\
\text { complanatum }\end{array}$ \\
\hline
\end{tabular}

Populations of Lycopodium alpinum were identified in grasslands dominated by Nardus stricta located at higher altitudes entering in the floristic composition of the association Violo declinatae-Nardetum Simon 1966. The populations occupied limited areas and were represented by vigorous individuals.

The species Lycopodium complanatum was rare in the site, and the population numbers are decreasing. It was identified at the edge of spruce forests but also in mountain meadows, in coenoses belonging to the Festuco rubraeAgrostietum capillaris Horvat 1951 association.

Due to the clonal nature of lycopods, it was difficult to estimate the abundance of species in the study plots by estimating the number of individuals on the surface. Therefore, a 5-level abundance scale was used in which the abundance of the aboveground shoots $/ \mathrm{m}^{2}$ was assessed: D-dominant, Aabundant, F-frequent, O-occasional, and R-rare. Analyzing the recorded results, the most abundant populations (60-100\% abundance) were identified at elevation level 1001-1300 m. Huperzia selago and Lycopodium annotinum were recorded with abundant/dominant populations also at altitudes between 801-1000 $\mathrm{m}$ asl. In the study area populations of Lycopodium alpinum were identified at the elevation level 1100-1300 m. They had the highest abundance values at elevation level
1201-1300 m, where the species was also dominant in the analyzed plots (up to 87.5\%). In the other plots, the species was occasionally or rarely (below $17.5 \%$ ).

Lycopodium annotinum had dominant and abundant populations, especially at altitudes between 1101-1300 $\mathrm{m}$ asl, but a significant number of abundant or dominant populations were found also at elevation level 801-1000 m. Abundant populations of Lycopodium clavatum were found between 900-1300 m asl. Only the populations of Lycopodium complanatum identified at 1001-1300 $\mathrm{m}$ asl had higher abundance, at other points the species were occasional or rare (Fig. 5-8).

The main threats to which Lycopodium species are exposed are generally related to human activities, infrastructure construction, forest clearing, changes in land use, as well as eutrophication and climate change. The abandonment of traditional land use, especially pasture, leads to the succession of vegetation, in the mountain area leading to reforestation. This results in the reduction of lycopod populations in the meadows. Lycopods (eg Lycopodium clavatum) are weak competitors because they depend on light and are disadvantaged compared to taller species. Pollution and eutrophication have a negative impact on lycopod species because they can affect mycorrhizae, the symbiotic partners of lycopods. 


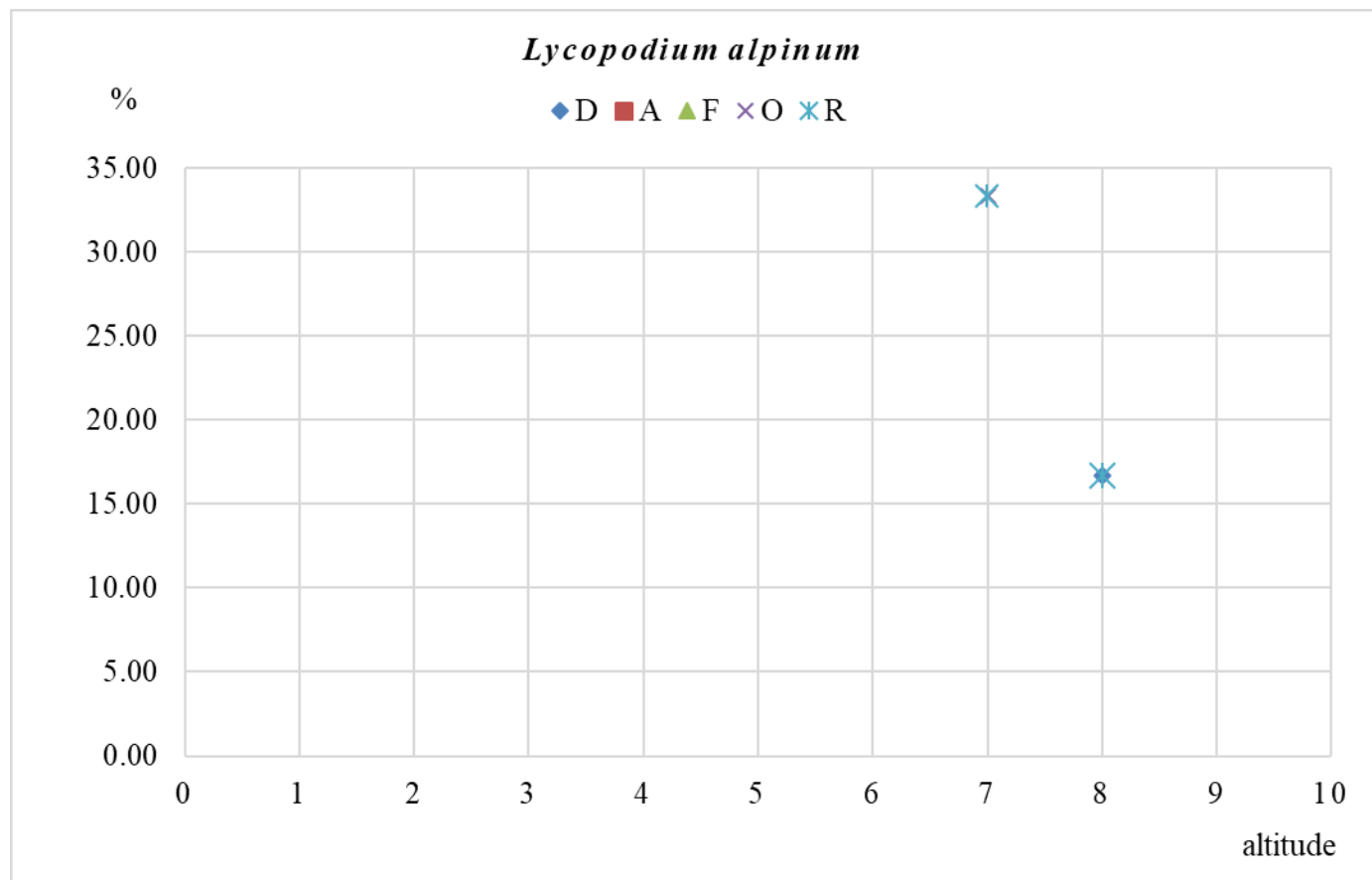

Fig. 5. Variation of the abundance along the elevation gradient in case of Lycopodium alpinum (Mureș County, Romania): D-dominant, A- abundant, F- frequent, O-occasional, and R-rare; Elevation levels: 1 (501-600 m), 2 (601-700 m), 3 (701-800 m), 4 (801-900 m), 5 (901-1000 m), 6 (1001-1100 m), 7 (1101-1200 m), 8 (1201-1300 m), and 9 (> $1300 \mathrm{~m})$.

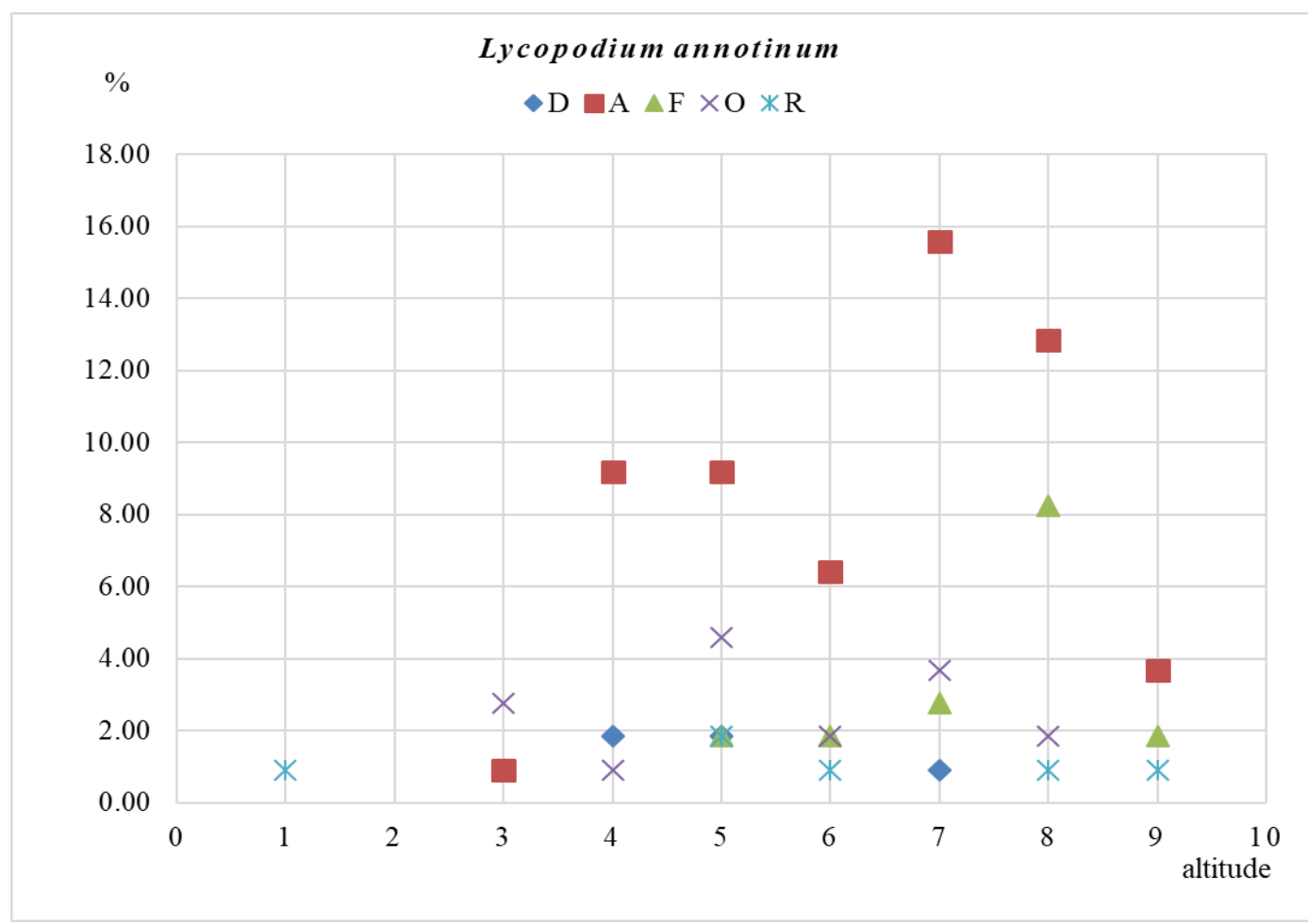

Fig. 6. Variation of the abundance along the elevation gradient in case of Lycopodium annotinum (Mureș County, Romania): see abbreviations at Fig. 5. 


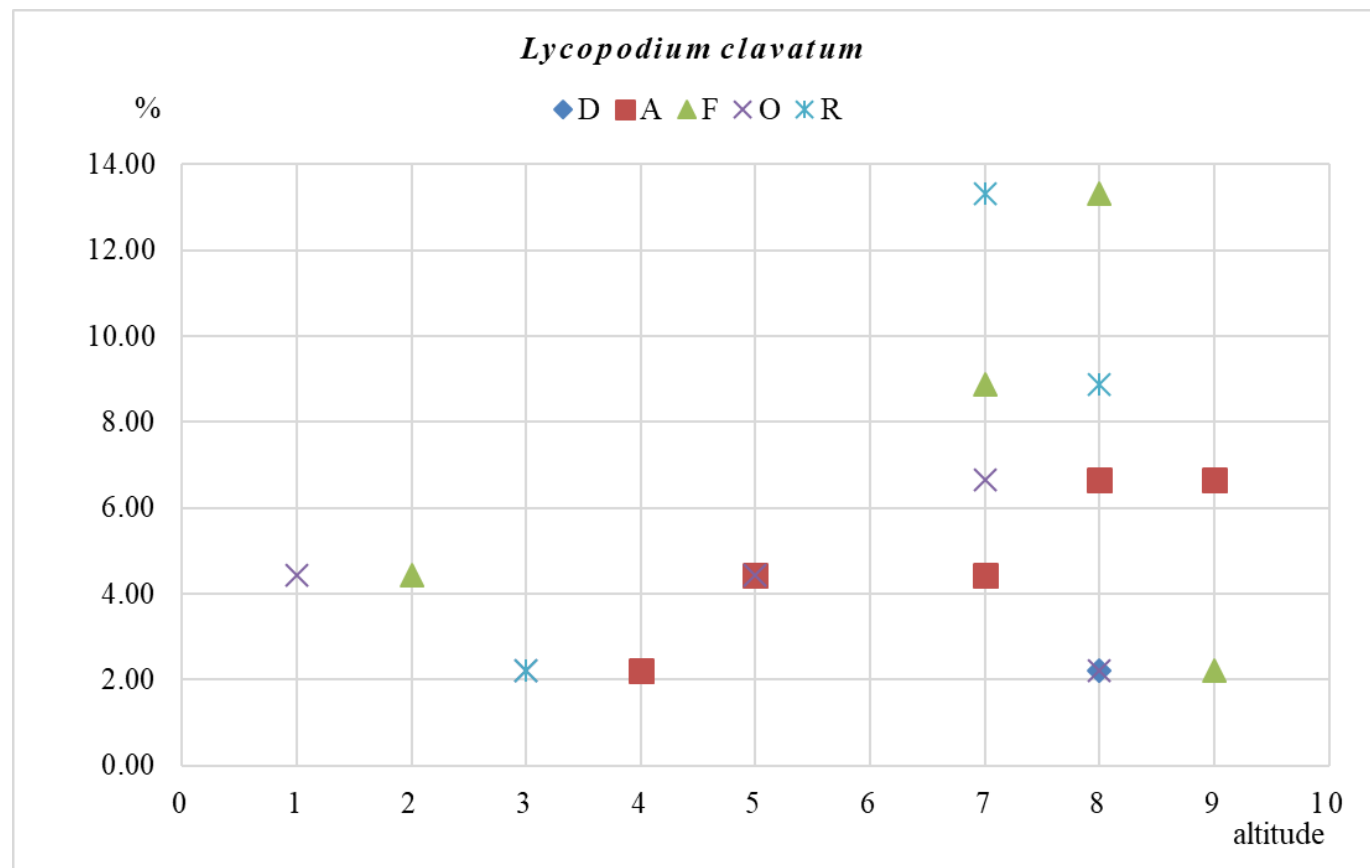

Fig. 7. Variation of the abundance along the elevation gradient in case of Lycopodium clavatum (Mureș County, Romania): see abbreviations at Fig. 5.

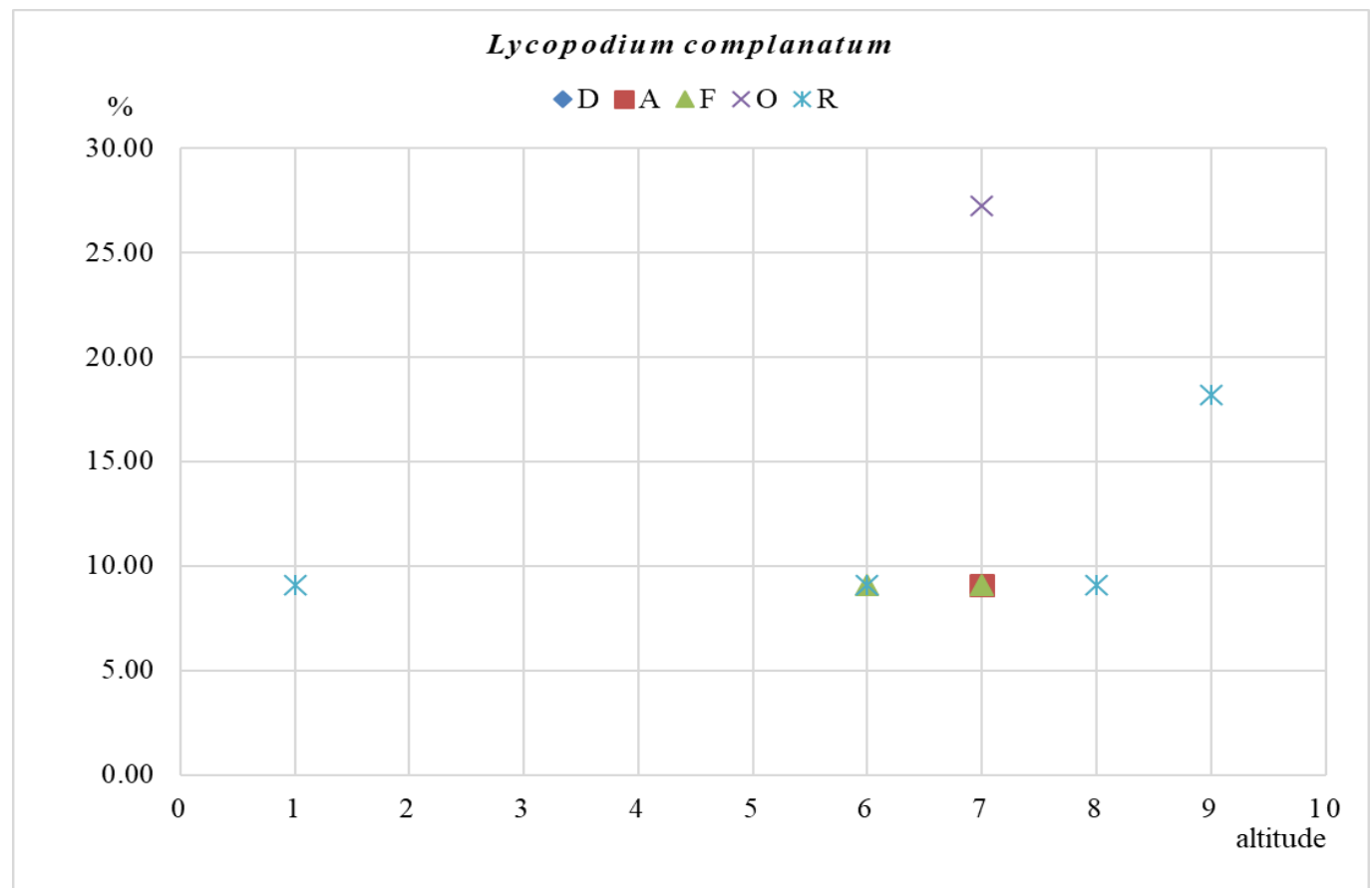

Fig. 8. Variation of the abundance along the elevation gradient in case of Lycopodium complanatum (Mureș County, Romania): see abbreviations at Fig. 5.

Tourism and animal trampling are factors that exert pressure on lycopods. However, the potential for regeneration of these species is high and therefore are not of high threat. The use of some species in traditional medicine is another threat, due to the irrational collections. Thus, Huperzia selago contains narcotic action principles. Selagoline, Huperzina A and serratidine alkaloids were identified in the species composition (Stærk et al., 2004). 


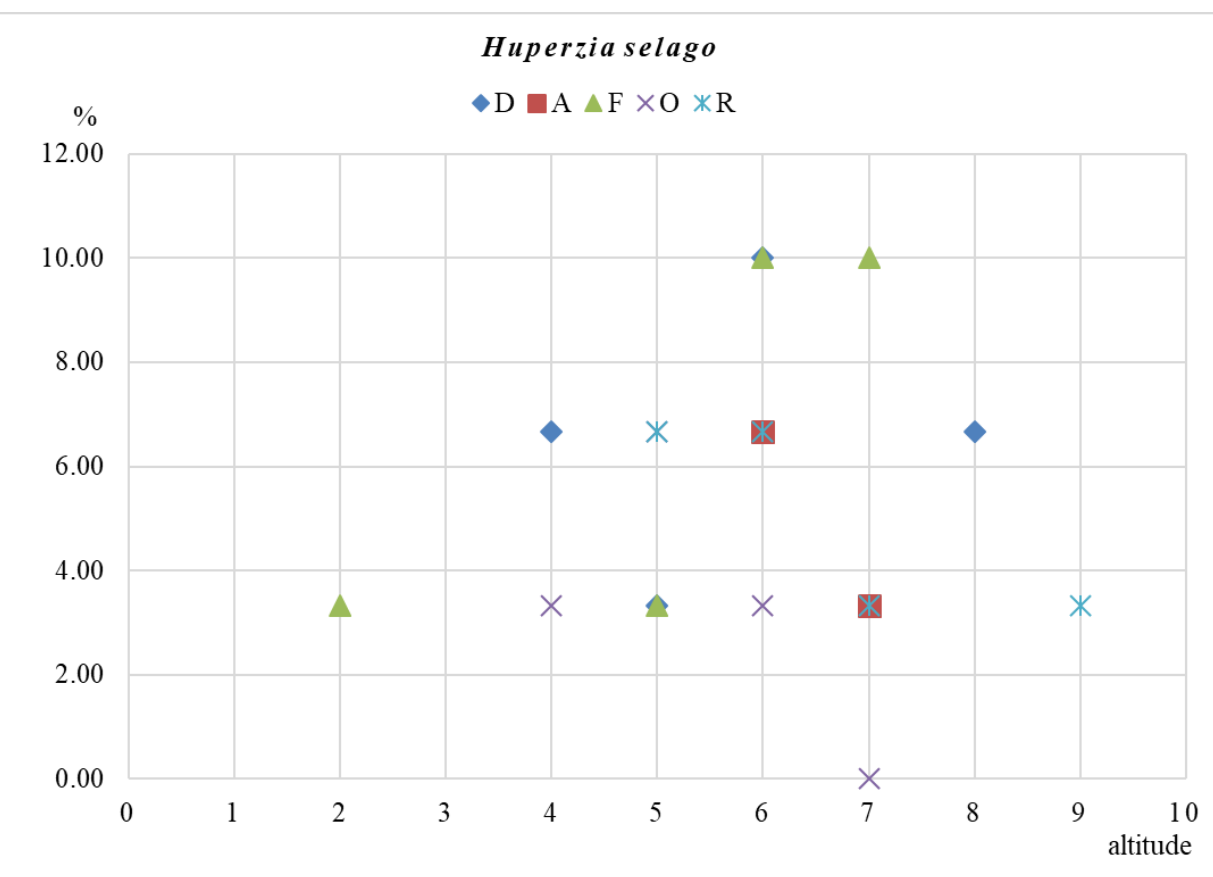

Fig. 9. Variation of the abundance along the elevation gradient in case of Huperzia selago (Mureș County, Romania): see abbreviations at Fig. 5.

Huperzine A is known to have neuronal protection properties used to improve memory and treatment behavior in Alzheimer's disease (Ma et al., 2007). Lycopodium clavatum is used in homeopathy for treatments of aneurysms, constipation, chronic lung and bronchial disorders, and fevers. It also reduces gastric inflammation, simplifies digestion and helps in the treatment of chronic kidney disorders. Lycopodium is used to treat various mental conditions such as anxiety, forgetfulness, and also relieves from tiredness and chronic fatigue (Jhilik Banerjee et al., 2014). Extracts from Lycopodium clavatum spores are used for the treatment of urinary, digestive, epileptic, pulmonary disorders, as well as rheumatism (Hanif et al., 2015). These two species are the most collected in the study area. The other species of lycopods, are also collected and used by locals as traditional remedies for different diseases.
The state of conservation of the identified populations is predominantly good and very good in the studied territory. Only in a few plots, where the anthropic pressure is higher, the conservation status is bad and populations are decreasing. The fact that the habitats in which these species have been studied are in a predominantly good state of conservation also indicates that the long-term evolution of species conservation state is stable.

The most important conservation measure for lycopod species concerns the conservation of their habitats. Because most of the observation points are in protected areas, the conservation measures provided for these areas also have a positive impact on maintaining the favorable conservation status of the species in the studied territory. Further studies are also required to establish and monitor the dynamics of these populations 


\section{Conclusions}

In the studied area 5 species of community interest belonging to the Lycopodiaceae family were identified: Huperzia selago, Lycopodium alpinum, L. annotinum, $L$. clavatum, and $L$. complanatum.

The most widespread of the identified species, are: Huperzia selago, Lycopodium annotinum and L. clavatum.

We can appreciate that although at the national level all species are sporadically encountered, in the study area Huperzia selago, Lycopodium annotinum, and L. clavatum can be considered species with high frequency, while L. alpinum and L. complanatum are rare.

All these species are of community interest and belong to the IUCN LC (Least concern) category.

\section{References}

1. Bilz M, Kell SP, Maxted N, Lansdown RV (2011) European Red List of vascular plants. Luxembourg: Publications Office of the European Union.

2. Ciocârlan V (2009) Flora ilustrată a României. Pteridophyta et Cormophyta. Ed. Ceres, Bucureşti

3. Coldea Gh (ed.) (2015) Les association végétales de Roumanie, Tome 3 Les associatios forestiéres et arbustives, Edit. Presa Universitară Clujeană\&Accent, ClujNapoca

4. Doniţă N, Popescu A, Paucă-Comănescu M, Mihăilescu S, Biriş Iovu A (2005) Habitatele din România, Ed. Tehnică Silvică, Bucureşti

5. Gafta D, Mountford O (coord.) (2008) Manual de interpretare a habitatelor Natura 2000 din România, Ed. Risoprint, ClujNapoca

6. García Criado $M$, Väre $H$, Nieto A, Bento Elias R, Dyer R, Ivanenko Y, Ivanova, D,
Lycopodium alpinum and L. complanatum are also included in the National Red List as rare species $(\mathrm{R})$.

The populations of the species are predominantly in a good and very good state of conservation, but a decrease of the populations can be expected in the future.

In order to avoid the tendency of declining populations and to maintain their favorable state of conservation, it is necessary to apply conservation measures and monitoring.

\section{Conflict of Interest}

The authors declare that the research was conducted in the absence of any commercial or financial relationships that could be construed as a potential conflict of interest.

Lansdown R, Molina JA, Rouhan G, Rumsey F, Troia A, Vrba J, Christenhusz MJM (2017) European Red List of Lycopods and Ferns. Brussels, Belgium: IUCN. iv + 59pp

7. Hanif K, Kumar M, Singh N, Shukla R (2015) Effect of homeopathic Lycopodium clavatum on memory functions and cerebral blood flow in memory-impaired rats. Homeopathy, 104(1):24-28

8. Jhilik Banerjee, Sunipa Biswas, Nithar Ranjan Madhu, Susanta Roy Karmakar, Merckx, V., Freudenstein, J., Kissling, J., Christenhusz, M.J.M., Stotler, R.E., Crandall-Stotler, B., Wickett, N., Rudall, P.J., Maas-van de Kamer, H. and Maas, P.J.M. (2012) Taxonomy and classification. In: Merckx V (ed.), Mycoheterotrophy, the biology of plants living on fungi. Heidelberg: Springer, pp. 19-104

9. Ma X, Tan C, Zhu D, Gang DR, Xiao P (2007) Huperzine A from Huperzia 
species-an ethnopharmacolgical review. J. Ethnopharmacol, 113:15-34.

doi:10.1016/j.jep.2007.05.030

10. Mihăilescu S, Anastasiu P. Popescu A. (2015) Ghidul de monitorizare a speciilor de plante de interes comunitar din România, Ed. Dobrogea, Constanţa

11. Oprea A (2005) Lista critică a plantelor vasculare din România, Ed.Univ. „Al. I. Cuza", Iaşi

12. Oroian S, Giurgiu M (2003) Plante medicinale spontane din Valea Nirajului, Rev. Medico-Chirurgicală a societăţii de Medici Naturalişti din Iasi, Supplement 1, 107(2):124-130.

13. Oltean M, Negrean G, Popescu A, Roman N, Dihoru G, Sanda V, Mihăilescu S (1994) Listă roşie a plantelor superioare din România, Studii, sinteze, documentaţii de ecologie, 1, Acad. Română, Instit. de Biologie, Bucureşti

14. Oroian, S, (1998) Flora şi Vegetaţia Defileului Mureşului între Topliţa şi Deda, Casa de Editură Mureş

15. Øllgaard B, Windisch PG (2014) Lycopodiaceae in Brazil. Conspectus of the family I. The genera Lycopodium, Austrolycopodium, Diphasium and Diphasiastrum - Rodriguésia, 2:293-309. http://www.scielo.br/pdf/rod/v65n2/a02v65 n2.pdf

16. Sămărghiţan M. (2005) Flora şi vegetaţia Văii Gurghiului, Ed. University Press, Târgu-Mureş

17. Sârbu I, Ştefan N, Oprea A, (2013) Plante vasculare din România, determinator ilustrat de teren. Ed. "Victor B. Victor", Bucureşti

18. Stærk D, Larsen J, Larsen LA, Olafsdottir ES, Witt M, Jaroszewski JW (2004) Selagoline, A new alkaloid from Huperzia selago, Natural Product Research, 18(3):197-203.

doi: 10.1080/14786410310001620600
19. Surjyo Jyoti Biswas (2014) A better understanding of pharmacological activities and uses of phytochemicals of Lycopodium clavatum: A review, Journal of Pharmacognosy and Phytochemistry, 3(1):207-210

20. *** Council Regulation (EC) No 338/97 of 9 December 1996 on the protection of species of wild fauna and flora by regulating trade therein ELI: http://data.europa.eu/eli/reg/1997/338/2017 $-02-04$

21. *** Habitats Directive 92/43/EEC - Concil Directive 92/43/EEC on the conservation of natural habitats and of wild fauna and flora (OJ L 206, 22.7.92)

22. *** Ordonanța de urgență nr. 57/2007 privind regimul ariilor naturale protejate, conservarea habitatelor naturale, a florei și faunei sălbatice 